\title{
偶発性低体温症に合併した 非閉塞性腸管虚血症（NOMI）の1例
}

$\begin{array}{llll}\text { 平野 洋平 } & \text { 林 伸洋 角由佳 井上 貴昭 } \\ \text { 松田 } & \text { 繁 岡本 健 田中裕 }\end{array}$

\begin{abstract}
要旨 非閉塞性腸管虚血症（non-opcclusive mesenteric ischemia: NOMI）は早期診断が難しく, 致 死率の高い疾患である。敗血症や外傷，急性膵炎などの循環不全を来す疾患に合併することがよ く知られているが, 我々は偶発性低体温症に伴う循環不全にNOMIを合併した症例を経験したの で報告する。症例は 74 歳の男性で, 意識障害を主訴に搬送された。来院時, 直腸温 $22.7^{\circ} \mathrm{C}$, 収 縮期血圧 $72 \mathrm{mmHg}$ と重度の低体温症と循環不全を認めており，加温輸液および体外式加温装置に よる復温を開始した。来院 4 時間後には体温は $36^{\circ} \mathrm{C}$ 台まで復温され，循環動態も安定した。しか し，その後再度徐々に循環動態は悪化し，大量輸液，カテコラミンに反応しない著明な乳酸値の 上昇を認め，ショック状態が遷延した。Disseminated intravascular coagulation（DIC）の合併も認 められ, 乾燥濃縮ヒトアンチトロンビン正製剤抢よび遺伝子組み換えトロンボモジュリンアル ファ製片投与を開始した。徐々に腹部膨満が増強し，エコー上腹水の貯留も認めたため，来院 48 時間後に腹腔穿刺を施行したところ血性腹水が確認された。緊急腹部造影 CT 検查施行し, 急 性腸管虚血症（acute mesenteric ischemia: AMI）の所見を認め，緊急開腹術を実施した。開腹する と Treitz 靱带より $20 \mathrm{~cm}$ 位から S 状結腸に至るまで，全層性の腸管壊死所見を認め，全小腸結腸切 除術を施行した。しかしながら術後循環不全を離脱できず，第4病日に死亡した。病理所見上， 腸管の全層性の虚血壊死を認めたが，血管内に血栓像は指摘されず，画像所見，術中所見と合わ せてNOMI と診断した。偶発性低体温症では, 復温までの循環不全の遷延化に起因すると考えら れるNOMIなどの AMIを合併する可能性をがあり，発症予防とともに早期の発見・治療に努め るべきである。

(日救急医会誌. 2013; 24: 437-42)

キーワード：循環不全，凝固障害，乳酸，壊死腸管
\end{abstract}

\section{はじめに}

急性上腸間膜動脈閉塞症や非閉塞性腸管虚血症 (non-occlusive mesenteric ischemia: NOMI) を含めた 急性腸管膜虚血症 (acute mesenteric ischemia: AMI) は, 腸管壊死から沉発性腹膜炎を経て敗血症性

A case of non-occlusive mesenteric ischemia (NOMI) with accidental hypothermia 順天堂大学医学部属浦安病院救急診療科

著者連絡先：干 279-0021 千葉県浦安市富岡 2-1-1

原稿受理日：2012年7月 5 日（12-072）
ショックに至り，その致死率は40-80\%に及ぶと報 告されている ${ }^{1,2)}$ 。早期の血管内治療や血行再建術 でviabilityのある虚血腸管は温存・再生が可能であ $り^{3)}$, 救命のためには早期診断, 早期治療が必須で あるが，発症早期には特異的な症状にそしく，その 診断には難渋することも多い。NOMIに関しては, 外傷や膵炎, 糖尿病性ケトアシドーシスなどの循環 不全を来す疾患に合併することがよく知られてい る。我々は偶発性低体温症に伴う循環不全にNOMI を合併した症例を経験したので，文献的考察を加え て報告する。 


\section{症例}

患 者：74歳の男性

既往歴：中咽頭癌

現病歴：最終確認より10日後, 仰臥位で倒れて いるところを発見され，当院へ救急搬送された。

来院時現症 : Glasgow coma scale E4V1M4, 血圧測 定不能, 心拍数 $33 /$ 分, $\mathrm{SpO}_{2}$ 脈波感知できず, 呼吸 数 $6 /$ 分, 直腸温 $22.7{ }^{\circ} \mathrm{C}$ であった。外見上, るいそ う著明であり，末梢虚脱，冷感を認めた。

腹部所見 : 腹部膨満所見なし。明らかな腹壁緊張 を認めず，腸雑音は正常に聴取された。

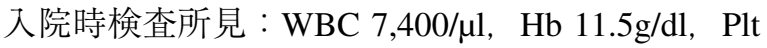

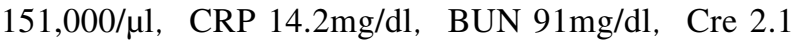
mg/dl, CK 1,833 IU/l, PT 61\%, PT-INR（prothrombin time-international normalized ratio） 1.41 （温度補正な L), FDP $22.9 \mu \mathrm{g} / \mathrm{l}$ 。

動脈血液ガス分析：(酸素 10Lリザーバーマスク下)

pH 7.612, $\mathrm{PaO}_{2} 275.9 \mathrm{mmHg}, \mathrm{PaCO}_{2} 17.5 \mathrm{mmHg}$,

$\mathrm{HCO}_{3}^{-} 19.4 \mathrm{mmol} / \mathrm{l}$, Base excess $-4.3 \mathrm{mmol} / \mathrm{l}$, Lactate $27.9 \mathrm{mg} / \mathrm{dl}$ 。

心電図：洞調律, 整であり, Osborn $\mathrm{J}$ wave を認 めた。

胸部レントゲン：異常所見を認めなかった。

腹部レントゲン：ガスによる腸管拡張像を認めた。

頭部CT（computed tomography）:頭蓋内出血や占 拠性病変は認めなかった。

治療経過：臨床経過および身体所見より, 直腸温 $22.7^{\circ} \mathrm{C}$ の偶発性低体温症に合併する循環不全と診断 した。急性期DICスコアは2点であった。気管挿管, 人工呼吸管理とし, 中心静脈路を確保し, 加温輸液 の急速投与, ドパミン塩酸塩 $5 \mu \mathrm{g} / \mathrm{kg} / \mathrm{min}$ 持続投与, および加温装置（エアパッド特定加温装置ベアーハ ガー；日本光電工業株式会社，東京）による復温を 開始し, 体温, 循環動態の改善を図った。並行して 意識障害, 偶発性低体温症の原因検索を行ったが, 頭蓋内出血性病変や虚血性心疾患, 感染症, 糖 - 電 解質異常等は否定的であった。また来院当初より,
著明な脱水症や低体温による心機能低下や循環不全 に起因する血液凝固立進の予防としてへパリンナト リウムの持続投与（9,600単位/日）を開始した。入 院後の体温, 循環動態, 凝固能の推移をFig. 1 に示す。 体温は来院 4 時間後には $36.7^{\circ} \mathrm{C}$ まで復温され, 細胞 外液 $1,000 \mathrm{ml}$ の急速負荷と復温によって, 血圧の上 昇, 乳酸值の改善を認めた。循環動態はいったん安 定したかと思われたが，来院6時間後に血清乳酸值 の再上昇を認め, また尿量も十分に得ることができ なかった。循環不全と判断し, 細胞外液 $500 \mathrm{ml} / \mathrm{hr}$ の 大量投与を実施し，昇圧荗投与を継続することによ り, 辛うじて尿量 $0.5 \mathrm{ml} / \mathrm{kg} / \mathrm{hr}$ を得られたが, 乳酸值 は高值で経過した。来院30時間後には急性期DIC ス コアで4点となったためDIC と診断し, 乾燥濃縮ヒ トアンチトロンビン III製剤および遺伝子組み換えト ロンボモジュリンアルファ製剤の投与を開始した。 入院 18 時間後より腹部膨隆が出現し, 次第に増悪し てきたため, 入院 48 時間後に腹水穿刺を施行したと ころ血性排液を確認した。遷延するショック状態と DIC 徵候を合わせて AMI 疑い, 緊急腹部造影 CT 検査を施行した。画像上，上・下腸間膜動脈根部の 狭小化を認め, また十二指腸, 直腸を除いて全小腸・ 結腸の腸管壁の造影効果が不良であった（Fig. 2)。 NOMIに伴う敗血症性ショックの診断で緊急開腹術 の適応と判断した。来院より 52 時間後, 開腹すると 血性腹水, 腸管浮腫を認め, 小腸から結腸は黒色調 に全層性壊死しており, 全小腸結腸切除術, 小腸瘻 造設術を施行した。しかし術後循環不全を離脱する ことはできず，第4病日に永眠した。病理所見とし て, 腸管の全層性の虚血壊死を認めたが，末梢血管 内に血栓像は指摘できず，NOMIの診断に合致する 所見であった (Fig. 3)。

\section{考察}

我々は偶発性低体温症にNOMI を合併した症例を経 験した。偶発性低体温症患者は，低温環境に長期暴 露された後に発見される例が多く，来院時には著明 な脱水症を合併することが多い。また低体温に伴う 

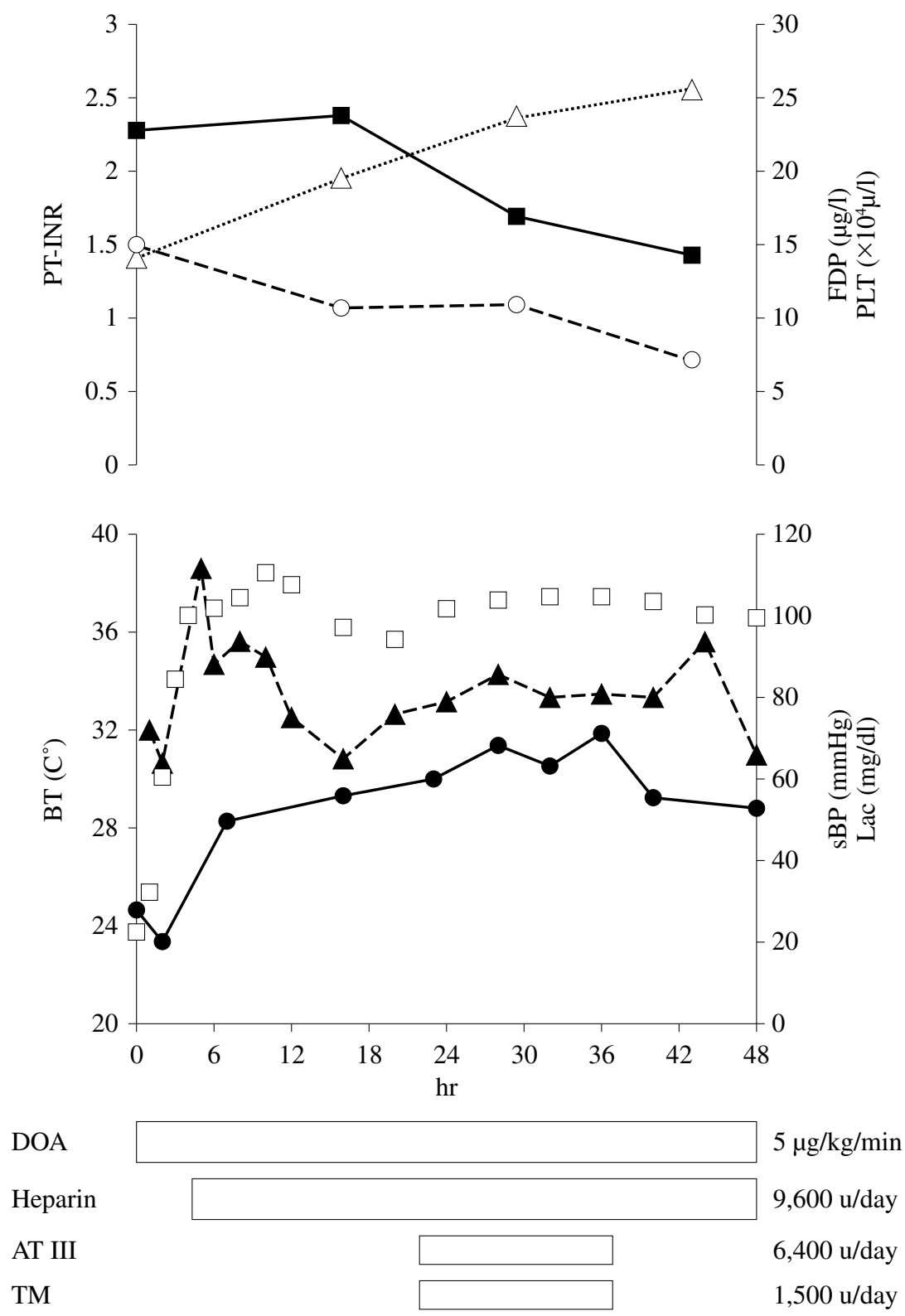

Fig. 1. Clinical course from admission to surgery.

$\triangle \triangle$ PT-INR: prothrombin time-international normalized ratio, $\bigcirc \bigcirc$ PLT: platelet, $\mathbf{\square}$ FDP: fibrin/fibrinogen degradation products, $\boldsymbol{\Delta}$ sBP: systolic blood pressure, Lac: lactate, $\square-\square$ BT: body temperature, DOA: dopamine, AT: antithrombin, TM: recombinant human soluble thrombomodulin

心機能低下から循環不全を来しやすく, 循環不全の 改善目的に昇圧剤の使用頻度が増える傾向にある。 このような低体温症が体内にもたらす二次的な要因 （脱水, 低心機能, 循環作動薬使用）は, NOMIの病 態の本質として考えられている腸管栄養血管の攣縮 を誘発する ${ }^{4,5)}$ 。本症例においても著明な血管内脱水, 心機能低下を認め, また血管作動薬使用が行われて
おり, NOMI発症に関与したものと考えられた。

我々が医学中央雑誌, PubMedを利用し, 検索し た限りにおいて，偶発性低体温症にNOMIを含めた AMI 合併した症例の報告論文は認められなかっ た。しかし学会報告（議事録）まで含めると，本症 例を含めて 5 例での報告例を認めたの)。年齢は 32 歳 から 86 歳と幅広く，来院時の体温は22.7-31.0들 

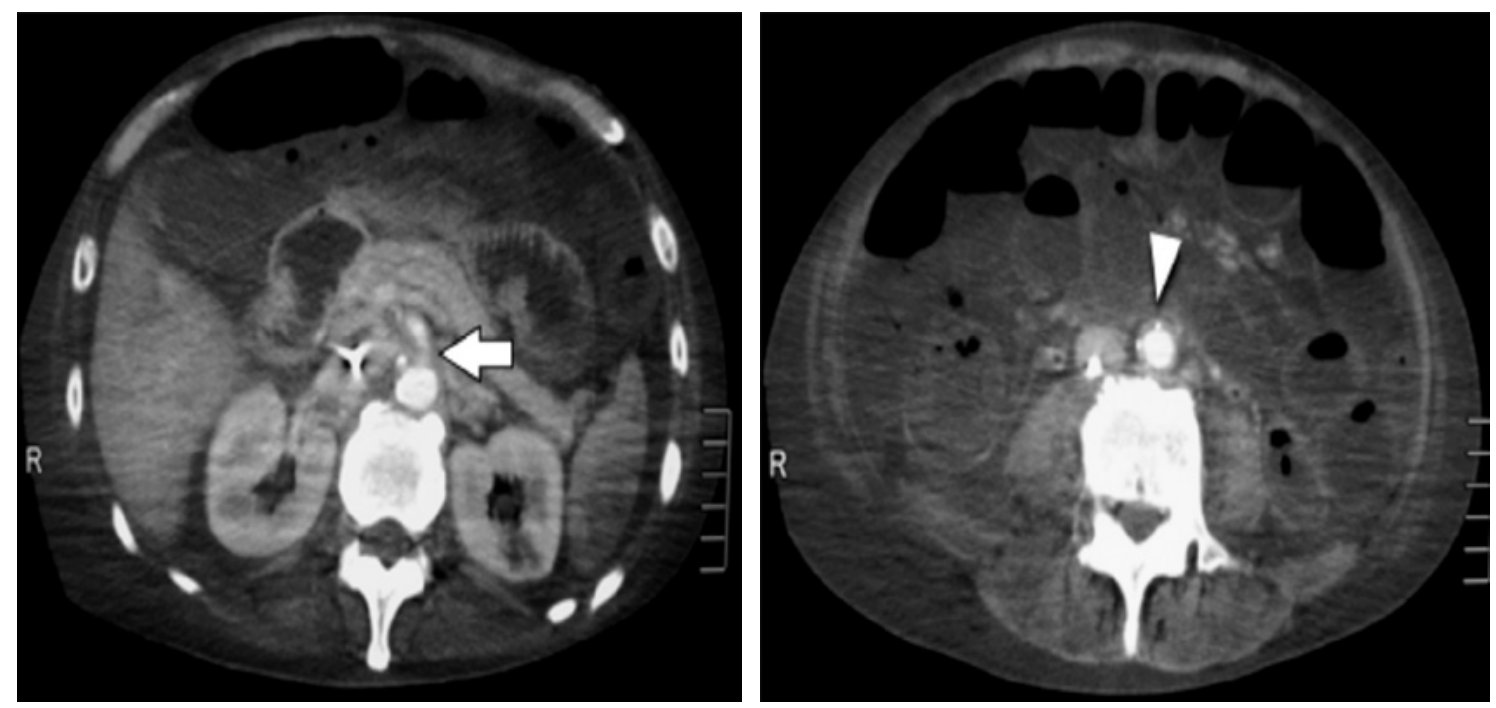

$\mathbf{a} \mid \mathbf{b}$

Fig. 2. Abdominal enhanced computed tomography images (48hr after admission).

a: Abnormal narrowing of the origin of the superior mesenteric artery can be seen (arrow) without a thrombus. Colon dilation and abnormal bowel wall enhancement are seen.

b: Abnormal narrowing of the inferior mesenteric artery can be seen (arrowhead) without a thrombus.
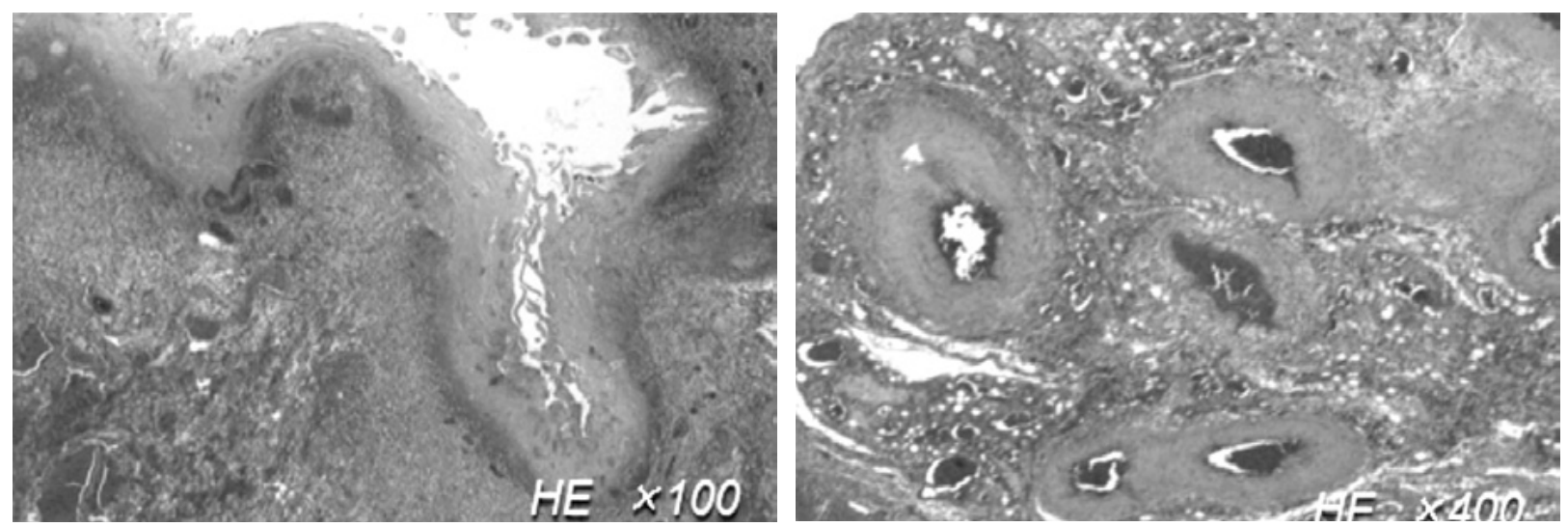

Fig. 3. Microscopic findings of the resected intestine.

Histrogical findings demonstrating transmural necrosis without blood clotting. (Hematoxylin and eosin staining; $\times 100, \times 400)$

て中等度から重度の低体温であった。これらの報告 例からは軽症偶発性低体温症にAMIを来した報告は なく，現在心肺停止蘇生後に広く普及している mild hypothermiaによる脳低温療法施行時はAMIのリス クは低いと考えられる。臨床所見として，復温後や 復温過程における腹部膨隆, 血性腹水, 血便が全例 で認められており，これまでに報告された5例では， 全例とも造影 CT 検査で確定診断を得ている。最終 診断は，3例がNOMI，2例が急性上腸管膜動脈閉塞 症であった。全ての症例で診断確定後に緊急開腹術
が行われたが，来院より6時間以内に診断に至った 2例は救命されたが，その他3例は死亡している。

一般的に低体温では，血液凝固能の低下と血小板 機能および血小板数の低下を来すことが知られてい る。低体温が与える生体に対する直接的作用とし て, 骨髄抑制と脾臓や肝臓での血小板の捕捉の増加 が挙げられるが, 結果的に末梢血液中の血小板数を 減少させる。さらに低体温は活性化凝固因子の酵素 活性を低下させることが知られており7)，PT-INRの 上昇と部分トロンボプラスチン時間の延長で示され 
る全般的な出血傾向が励起されるというのが通説で ある。

しかしながら, 一方では低体温環境は血栓傾向を もたらすという報告も存在する。2005年, Lindenblattら ${ }^{8)}$ は, 低体温環境に暴露させたマウスの精巣 挙筋標本を用いて, 低体温環境下 $\left(34^{\circ} \mathrm{C}, 31^{\circ} \mathrm{C}\right)$ で は血小板上の GP IIb-IIIa受容体活性が上昇し, 血小 板凝集促進により，微小血管内血栓形成が充進する ことを報告した。またRuckerら ${ }^{99}$ は，環境ストレス 下で放出される hemoxygenase 1（HO-1）による血 液凝固抑制効果を調査する目的で, $4^{\circ} \mathrm{C}$ の低温に暴 露させたマウスを用いたが, 結果として逆に微小血 管の血栓形成促進が認められたことを報告した。以 上のように, 低体温症における血液凝固能に関して は, 出血傾向に傾くという意見の一方で, 血栓形成 を促進するという報告もあり，一定の見解を得られ ていないのが現状である。

また長時間の低温環境への暴露や寒冷利尿は, 血 管内脱水や血液濃縮をもたらし, 赤血球変形能の消 失と合わせて血液粘度を上昇させる ${ }^{10)}$ 。血液粘度の 上昇は，血液凝固六進に働くと考えられ，そのため 偶発性低体温症例に関しての凝固機能を体温のみで 推し量ることには限界があろう。実際の臨床の場で は, 凝固能検査や臨床徵候から各症例の血液凝固能 を判定することが最も重要であると考える。ただ し, APTT (activated partial thromboplastin times), PT (prothrombin times) などのデータの解釈にも注意が 必要である。測定系温度を個体温度に一致させなけ れば，実際に生体で起こっている凝固機能を正しく 評価できないとの報告もある ${ }^{11,12) 。 ~}$

本症例では入院時にはDICの診断基準は満たさ ず，復温後に血小板減少と PT の延長が進行し DIC となったことから，低体温からではなく腸管虚血に 伴う septic DICが発症したと考えている。そのため 低体温に起因するDICによる末梢血管閉塞がNOMI 発症の主要因であったとは考えづらい。

本症例の反省として, 来院から NOMIの診断に至 るまでに約 48 時間を要していることが挙げられる。
その要因として, 来院時からの意識障害や鎮静，鎮 痛薬投与のため, 腹部所見が正しく得られなかった ことや，脱水症を基礎とした腎機能障害で造影 CT や血管造影検查を躊躇したことが挙げられる。本症 例に限らず，循環不全に伴うNOMIでは意識障害や 腎機能障害を伴うことも少なくない。NOMIは, 早 期診断が救命のために何より重要であり，偶発性低 体温などで遷延する循環不全を来した症例では, AMI 念頭に置き, 診断のための造影検査を躊躇 しないことが重要である。本症例は早期には腹腔穿 刺できるほどの腹水貯留は認めなかったが, 腹水の 性状も早期診断には重要である。

また本症例では脱水症に対して大量補液が行われ ており, 腹部コンパートメント症候群（abdominal compartment syndrome: ACS）の合併から循環不全を 来し, NOMIが発症した可能性も否定できない。し かしながら, CVP (central venous pressure) やIAP （intra-abdominal pressure）の測定は本症例では行わ れず，ACSが起こっていたかどうかは不明である。 すなわち低体温での NOMI 発症の病態に関して, 脱 水症, 心機能低下からの循環不全やカテコラミン使 用などが血管攣縮を誘発し, NOMIを発症せしめて いるのか，または大量補液によるACSによる循環 不全がその病態の根幹をなすのかの鑑別が困難で あった。したがって, 偶発性低体温症の復温過程に おいて, 循環動態が安定するまでの抗凝固療法の導 入，腹腔内圧の持続的モニタリングなど，AMIの 発症を予防し，早期発見する診療指針が重要と考え られる。

\section{まとめ}

偶発性低体温症では二次的な血管内脱水や心機能 低下に伴う循環不全, さらには治療としてのカテコ ラミン使用の増加から NOMI を発症するリスクが高 い。NOMIは早期診断，早期治療が予後を左右する 疾患であることから，偶発性低体温症例ではNOMI の合併の可能性を十分に考える必要がある。またカ テコラミン製剤の使用をできるだけ控え，腸管虚血 
が疑わしければ積極的な造影CT検査や血管造影検査

を行い，早期診断に努めるべきである。

\section{文献}

1) Nonthasoot B, Tullavardhana T, Sirichindakul B, et al: Acute mesenteric ischemia still high mortality rate in the era of 24hour availability of angiography. J Med Assoc Thai. 2005; 88 Suppl 4: S46-50.

2) Acosta-Merida MA, Marchena-Gomez J, Hemmersbach-Miller M, et al: Identification of risk factors for perioperative mortality in acute mesenteric ischemia. World J Surg. 2006; 30: 1579-85.

3) Brandt LJ, Boley SJ: AGA technical review on intestinal ischemia. American Gastrointestinal Association. Gastroenterol. 2000; 118: 954-68.

4) Alhan E, Usta A, Çekiç A, et al: A study on 107 patients with acute mesenteric ischemia over 30 years. Int J Surg. 2012; 10 : 510-3.

5) Darwood R, Smith FCT: Vascular surgery - I Mesenteric isch- emia. Surgery. 2012; 30: 420-6.

6) 井上貴昭, 鍬方安行, 杉本壽: 腹部急性疾患の鑑別診断. 消臨. 2003; 6: 633-9.

7) Watts DD, Trask A, Soeken K, et al: Hypothermic coagulopathy in trauma: effect of varying levels of hypothermia on enzyme speed, platelet function and fibrinolytic activity. J Trauma. 1998; 44: 846-54.

8) Lindenblatt N, Menger MD, Klar E, et al: Sustained hypothermia accelerates microvascular thrombus formation in mice. Am J Physiol Heart Circ Physiol. 2005; 289: H2680-7.

9) Rücker M, Laschke MW, Stamm A, et al: Local preconditioning by thermal stress accelerates microvascular thrombus formation. Shock. 2009; 31: 627-33.

10) Poulos ND, Mollitt DL: The nature and reversibility of hypothermia-induced alterations of blood viscosity. J Trauma. 1991; 31: 998-1000.

11) Reed RL 2nd, Johnson TD, Hudson JD, et al: The disparity between hypothermic coagulopathy and clotting studies. J Trauma. 1992; 33: 465-70.

12) Rohrer MJ, Natale AM: Effect of hypothermia on the coagulation cascade. Crit Care Med. 1992; 20: 1402-5.

\title{
ABSTRACT \\ A case of non-occlusive mesenteric ischemia (NOMI) with accidental hypothermia \\ Yohei Hirano, Nobuhiro Hayashi, Yuka Sumi, Yoshiaki Inoue \\ Shigeru Matsuda, Ken Okamoto, Hiroshi Tanaka \\ Department of Emergency and Critical Care Medicine, Juntendo University, Urayasu Hospital
}

\begin{abstract}
Non-occlusive mesenteric ischemia (NOMI) is difficult to diagnose in the early phase and often has a poor prognosis. Circulatory failure is a known risk of NOMI. A 74-year-old man with accidental hypothermia complicated by NOMI was admitted to our hospital in an unconscious state. On admission, circulatory failure was observed, and his rectal temperature was $22.7^{\circ} \mathrm{C}$ and systolic blood pressure was $72 \mathrm{mmHg}$. Rewarming was performed by warm fluid infusion using a heating system. His temperature increased to approximately $36^{\circ} \mathrm{C}$ after 4 hours of rewarming along with temporary stabilization of hemodynamic parameters; however, hyperlactatemia and circulatory failure resistant to fluid infusion and inotropic support gradually developed. He developed disseminated intravascular coagulation, and antithrombin and recombinant human soluble thrombomodulin therapy was initiated. Forty-eight hours after admission, abdominal computed tomography findings along with hemorrhagic ascitic fluid collected by paracentesis suggested acute mesenteric ischemia (AMI). Emergency enterocolectomy was performed; however, the patient died 4 days after admission. Histopathological findings included transmural necrosis without blood clotting, which was consistent with the diagnosis of NOMI. Because accidental hypothermia can induce AMI, early diagnosis and management are imperative.
\end{abstract}

(JJAAM. 2013; 24: 437-42)

Keywords: circulatory failure, coagulation disorder, lactate, necrotic intestine

Received on July 5, 2012 (12-072) 